\title{
Value-Motivational Characteristics of Innovativeness as Prospects for Successful Self-Fulfillment
}

\author{
Olga B. Mikhailova \\ Peoples' Friendship University of Russia \\ Email:Olga00241@yandex.ru \\ Sergey I. Kudinov \\ Peoples' Friendship University of Russia \\ Email: rudn.tgu@yandex.ru \\ Karl G. Marin Jerez \\ Peoples' Friendship University of Russia \\ Email: karlmaring@gmail.com
}

Doi:10.5901/mjss.2015.v6n3s2p105

\begin{abstract}
Innovative capacity of a personality is one of the most important constituents of human capital assets. The development of innovation activity in a personality is impossible without the goals, values and motives of self-fulfillment. Nowadays both a modern researcher and a practicing psychologist take a particular interest in personal traits' developmental level and peculiarities of the value-motivational moments in groups with various degrees of expressiveness. Particularly, a practicing psychologist works out and manages psycho-technology of the value-motivational personality sphere for effective selffulfillment in society. The study of the value-motivational features of young students with various degrees of innovativeness was conducted. The article considers re-examinations to an analysis and a research of the value-motivational features of the individual innovativeness activity. The paper also presents a comparative and empirical analysis of the above-mentioned characteristics of young students. The recent data on a personal and gender-based value-motivational sphere and an innovativeness demonstration were presented in terms of the specified research policies and ground results. The results of the study are of particular interest for practicing psychologists who can broaden the sphere of personal value-motivational structure investigation and determine the basic ways of psychocorrective work in effective human capital assets development. The diagnosis of the value-motivational innovative activity and the elaboration of the personal developmental programmes are the fundamental basis for the innovative personality potential improvement and self-fulfillment in professional career.
\end{abstract}

Keywords: innovativeness, innovative potential, value-motivational sphere of innovative personality, self-fulfillment.

\section{Introduction}

The success of self-fulfillment is determined by a set of personal qualities that enable a person to achieve effective results. The phenomenon of self-fulfillment, including educational and professional activities, is inextricably linked to selfdevelopment and active management of personal resources. One of the markers that characterize the social performance of self-fulfillment is the innovativeness of a personality.

In nowadays society, the problem of individual creativity demonstration study has determined the necessity of the creation of new managing forms in personality development. In search of boundaries between personal success, effectiveness and efficiency, new leaders emerge whose activity can be of advantage and disadvantage to themselves and society. The prospect of psychological trends in character research is attributed to the identification of youth's valuemotivational aspects of behaviour and activities. In addition, effective implementation of socio-psychological activity control technologies for socio-economic development of society is involved as well.

Russian and foreign scientists point out common psychological activities of an individual as one of the idiosyncrasy markers.

Consequently, contemporary personality psychology regards mental activity as a human activity characteristic. The activity can be viewed as a valuable way of modeling, structuring and actualizing of communication and conduct by a 
personality. The activity is a characteristic of performance with an independent immediate power. It is expressed in free, conscious, internally necessary work. A bundle of socio-psychological traits and qualities determines activity and lets a personality manage it by means of values and motives. Consequently, socially-oriented value-motivational creative activity can be taken into consideration.

Social and personal values stand out as a human activity mark which allows estimating and using activity in relation to reality. Truth and lie, admissible and forbidden, fair and unfair play an important role in person's construction of demands and motives, idiosyncrasy and activity. The individual does not always apprehend values and does not lose the regulatory influence on personal enhancement.

The system of values constructs individual values and motives. Value-objective norms and mindsets influence the development of the motives that predetermine the individual effectiveness.

Considerably, innovative conduct is predetermined by the peculiarities of values and motives, the structure of which has not been studied yet. The search of differences and relationships between value-motivational system and innovative manifestations will show up the system of value-motivational characteristics (Mikhailova, 2010).

The article suggests a methodological analysis of personal innovativeness, which is considered to be a multidimensional, intergrated quality. The empirical research results are examined on the basis of the conducted analysis, while the research itself was aimed at determining value-motivational characteristics of innovativeness in students. The author hopes that the article materials will be of interest and importance to practicing psychologists and will be useful in developing new technologies of successful self-fulfillment management.

\section{Literature Review}

Innovative and initiating causes of behaviour are the foundation of innovative activity organizations and are correlated with the study of the individual potential. The concept of human potential is characterized in various trends of its study: social and organizational, economic, social and environmental, existential. The notions of psychophysiological capacity (V.I. Medvedev, G.M. Zarakovsky), professional and personal potential (V.N. Markov), adaptive potential (A.G. Maklakov), leadership potential (A.N. Zankovsky) innovative potential (V.E. Klochko, E.V. Galazhinsky), intellectual potential (B.G. Yudin) are stated.

The common feature of all above-mentioned approaches is that personal potential is determined by means of successful self-realization in a particular activity and resolved into a set of abilities and skills, as well as the fulfillment of this activity. The attributive schemes and strategies are the key variables for understanding the nature of a personal potential as a self-regulation potential (Leontiev, 2011).

The attributive schemes are developed under the influence of personal experience. This is called the representation system of ideas about the world structure; orientational basis which has an impact on personal decisions, activity and aims. The strategy is a stable focus of our conduct or a sustainable way of behavior which is consciously selected and subjected to deliberate changes. It is a stable mark for managing its own voluntary action. According to A.D. Leontiev's theory, the structure of personal potential consists of the following components: optimism; hardiness; personal self-regulation; self-efficacy; ambiguity tolerance; control over action; reflectivity; subjective vitality (vitalpower) (Leontiev, 2011). Each of the above mentioned features is a rather complex multiple quality and involves comprehensive theoretical and empirical analysis.

Obviously, the personal potential studying, substituting human assets research problem, provides an opportunity to define main perspective research trends: 1) the nature of the variables characterizing a personal potential; 2) the methodology of grounding and empirical definition of the dominant components; 3) the research strategy and research methods tool set; 4) the establishment of a new diagnostic tool set; 5 ) technology support elaboration and the formation of personal development potential at different age times; 6 ) the development and maintenance of personal psychological assets (psychological resources).

To determine the formulated perspective trends of personal potential research it is necessary to use the systemic and functional approach to personal qualities examination. This trend in the study of personality originates from Russian psychological theoretical statements: the inseparability of dynamic, meaningful and productive mental activity aspects (Brushlinsky, 1978; Nebylitsyn, 1976, Rubinstein, 1973, Krupnov, 1990, etc.), the unity of personal and individual subject composition (Ananiev, 1980; Golubeva, 1983, 1993; Lomov, 1984, Merlin, 1985, etc.), the systemic nature of personal relationship (Abulkhanova-Slavskaya, 1991; Bodalev, 1988; Myasischev, 1960, Krupnov, 2006).

S.L. Rubinstein points out that the systemic nature of personal traits represents the image fusion of thoughts, feelings, impulses in unity and interpenetration with the objective consecution and the results of actions. V.D. Nebylitsyn's theory was based on the study of the connections between meaningful, dynamic and productive aspects. B.G. Ananev 
suggested that individual personality traits comprised not only presentational relationship, but the ways of its fulfillment, motives, emotional, intellectual and productive characteristics as well. A.A. Bodalev claims that personality traits are the integration of private relations to various events. It represents the unity of knowledge, experience and behavior. The analysis of theoretical statements indicates a multiple structure of personality traits as opposed to a one way interpretation (Mikhailova, 2013).

In the early 1980s, Russian academician Alexander Ivanovich Krupnov introduced a well-founded, systemic and dispositional approach to the study of personality and its traits. (Krupnov, 2006). According to systemic and dispositional approach, innovative personal potential can be considered as highly effective combination of personal activity forms, required for the practical innovative fulfillment.

Innovativeness is viewed as a further creativity staging point, a benchmark of immediate assessment and practical embodiment of innovations, a certain socio-organized practice. Therefore, innovativeness can be defined as a person's ability to understand, receive, estimate socially, spread, implement and use innovations. Innovativeness can be fully expressed in business activity (Mikhailova, 2012).

The bases for innovative activity development are values and motives of an individual. Consequently, valuemotivational system actively determines personal innovativeness, acting both prerequisite and a blocker.

The value-motivational relation to innovative activity is defined both as a set of internal necessity and the availability of external conditions and socially established values.

The system of values is the " basis» of relationship to the world. Values can be considered as a relatively stable, socially conditioned selective and conscious attitude to the set of human unspiritual and spiritual matter of society. Motivational sphere is traditionally pointed out in various activities as a link which makes action purposeful and determines the personal potential. Problems of motivation and motives have been widely covered in the works of Russian and foreign psychologists (V.G .Aseyev, E.P. Ilyin, V.I. Kovalev, K. Levin, A.N. Leontiev, G.F. Lomov, A. Maslow, V.E. Milman, J. Nyutten, S. L. Rubinstein, B.A. Sosnovsky, H. Heckhauzen, etc.).

The research and development of value-motivational activity of the innovative participants is essential for every sphere of professional activity. The transition from traditional system to the innovative fulfilment requires new ways of solving problems. This implies a serious stereotype breakage associated with changes in the approach to the objectives, forms and methods of activity.

The indicators of motivational readiness for innovativeness are as follows (Koptyaeva, 2009):

interest expression in innovation and its dynamics - a positive attitude towards innovation, the desire to be involved; experience of the positive emotional states about innovation, striving desire to assess own professional and personal experience from the point of innovation; positive attitude towards the perspectives of innovation;

- Self-actualization maturity motive - awareness of own capabilities, the necessity to improve oneself, growing more confidence;

- Overcoming difficulties maturity motive - awareness of the individual insufficient achievements and the desire to improve it; understanding of problems, independence in its solving and responsibility.

The problem of innovative activity motivation should be considered as a problem of acquisition of the adequate personal meaning of professional activities. Due to the motives mismatch, discomfort condition results in labour deprivation of personal self-development and creativity. It turns from personal value into the means of livelihood. The management development of personal potential is very important to return a creative and a productive labour value in a modern practice. Studying the needs, youth's interests and values, the educational environment should influence on new generations motives system. In such a way the personal activity must be expressed in a constructive behavior and activities. Consequently, if the personality development properly managed, the value-motivational activity is expressed in new activities results.

In psychological studies, activity is considered as a specifically human form of an active attitude towards the world. The essence of that form consists in a reasonable change and world transformation based on development of available forms of culture. Innovative activity aims at existing forms transformation and methods of professional activities, awareness and the creation of new aims and the means of realization. That is why the result of this activity leads to the expected progress of society. In P. Y. Anokhin's, B.F. Lomov's, A.N. Leontiev's works, the psychological analysis of activity the structure is given. It is viewed as a dynamic action system, arising and reorganizing under the controlling influence of a complicated with result and motivation interactions.

Due to the fact that multiple relations with the environment are presented in a relatively stable personal motivational sphere, any activity as well as innovative, usually correlates with more than one motive. Therefore, it becomes multimotivational.

As far as motives are not recognized except the conscious motives, and even hidden from other people, one has to 
answer the actual questions: in which direction, which actions are constructed on, which orientation is used in the context of value-motivational personality traits?

The motivational component of innovative activities is necessary to be considered in two ways. First, from the point of location of professional motivation in the overall structure of motives and, secondly, having estimated the individual concern to changes, i.e. having identified needs in innovations, susceptibility features that determine the content of creative professional directivity.

The diagnosis of the value-motivational innovative activity and elaboration of development activity programmes are fundamental conditions of innovative personality potential improvement and self-fulfillment in professional activity (Lebedeva, Bushina, Cherkasova, 2013).

S.I. Kudinov defines the phenomenon of self-fulfillment as a system of component parts which include micro and macro elements. All the elements of this model interact closely, and any change in one of them affects the operation of the other elements. (Kudinov, 2007).

Psycho-ecological, physiological, psychological, educational and social factors are basic conditions for selffulfillment of a personality. (Kudinov, 2013)

Among the forms of self-fulfillment can be identified external and internal. External forms are aimed at individual self-expression in different spheres of life: career, sports, arts, academic, political and social activities and others, while the interior forms provide cultivation of physical, intellectual, aesthetic, moral and spiritual aspects of a personality.

Finally, it is necessary to allocate active, social and personal self-fulfillment among the types of self-fulfillment manifestation. The active one is characterized by successful self-expression in a variety of activities and provides a high level of professional competence. Social self-fulfillment is associated with the implementation of the humanitarian mission, socio-economic, socio-political, socio-educational or any other socially useful activities. Personal self-fulfillment promotes spiritual growth, providing the first stages of personal potential development: responsibility, curiosity, sociability, diligence, perseverance, initiative, knowledge, creativity, morality, etc. (Kudinov, 2013). The given methodological approach allows to examine the multidimensionality of personal qualities and traits in a most complex way and to develop an empirical research strategy, aimed at discovering effective technologies of personal self-realization in society.

Dynamic changes which take place in modern society shape the strategies of personal self-fulfillment. These strategies provide a possibility to enter innovative society and to gain effective results of activity. The success of selffulfillment, including innovative activity, is based on values and motives. The analysis of developmental specifics in valuemotivational sphere of young adults and the creation of positive motivational environment are the foundations of successful personal self-fulfillment in society.

\section{Method}

\subsection{Participants}

The article provides an analysis of the characteristics in the value-motivational structure in groups with different levels of innovative manifestations. 140 students studying at the Faculty of Economics (Peoples' Friendship University of Russia) were involved into empirical research. Their age ranged from 19 to 21 years old. The following diagnostic methods were provided: «The scale of innovative personality traits self-assessment» (N.M. Lebedeva, A.N. Tatarko); «Motivational personality structure questionnaire» (E. Milman); Real structure of personal value orientations questionnaire (Bubnova C.C.).

\subsection{Materials}

For the diagnostics of innovativeness parameters a self-evaluation scale of innovative qualities in a personality was used (N.M. Lebedeva, A.N. Tatarko). This questionnaire was designed to measure attitudes to innovation. The questionnaire consists of 12 statements with which the respondents can compare themselves (possible answers - "Not like me at all", "Not like me", "A little like me", "Like me", "Very much like me" ). According to the responses the general level of innovativeness (index of innovation) is revealed.

For the qualitative analysis of innovativeness constituents the division on subscales can be used:

1) Creativity: 4,5,8,10.

2) Risk for success: $3,6,11,12$

3) Focus on the future: $1,2,7,9$.

Indicators on all scales and personal innovativeness index range from 1 to 5 points. 
For the diagnostics of value orientations the technique "Diagnostics of the actual structure of personal value orientations" by S.S. Bubnova, which is designed to study the implementation of personal value orientations in real life. The technique contains 66 closed questions, with which the respondent can agree or disagree (possible answers - "Yes" or "No"). The responses reveal the prevailing values of a testee. The technique includes 11 scales. The degree of each of multistructural personal value orientations representation is determined by using a key represented in an answer form. Accordingly, the number of positive responses in all eleven columns is calculated (described below).

For the diagnostics of the motivational structure the questionnaire of personal motivational structure worked out by V.E. Milman and identifying the predominant types in human motivation was used. The technique also allows to identify some steady personal trends: general and creative activity, desire to communicate, comfort and social status maintenance and others. On the basis of all responses a judgement on working (business) and everyday orientation of an individual can be made. The questionnaire consists of 14 statements relating to life aspirations and certain aspects of a person's lifestyle and includes the following types of motivation:

1. "Life maintenance"

2. "Comfort"

3. "Social status"

4. "Communication"

5. "General activity"

6. "Creative activity"

7. "Social utility"

\section{Results}

Data factor analysis showed that the group with a low level of innovation focused on values such as the search of pleasure (0.76), love (0.88), the recognition and respect of the people and the impact on the surrounding $(0.75)$, and social activity for achieve positive changes in society $(0.79)$.

In the future, a group of students with a low level of innovation focused on the high level of material well-being (0.85), communication (0.66), and high social status and people management $(-0.69)$.

Among the leading motives of the group leading the overall activity (0.71) and everyday motivation (0.68).

The results of the factor analysis in the group with an average level of innovativeness revealed the following structure of values - a pastime, recreation (0.65), high material well-being (0.71); Search and enjoying beautiful (0.72), help and compassion for others (0.69) love (0.68), the new knowledge in the world, nature and man (0.75), high social status and people management $(081)$, the recognition and respect of the people and the impact on the surrounding (0.90), social activity in order to achieve positive change in society. (0.92), although in the future, this group is not focused on the development of their creative potential, but the system of values and motivational aspects of the future is not clear. Furthermore, the structure of the dominant motives are not revealed.

In the group with a high level of innovation structure of value orientations represented by indicators such as love, new knowledge in the world, nature and man (0.81), love (0.74), high social status and people management $(0.83)$, recognition and respect people and the impact on the surrounding (0.81), social activity in order to achieve positive change in society; (0.95).

In the future, this group of students focused on the high level of material well-being (0.72), help and compassion for others, (0.65), search and enjoying beautiful (0.70), the recognition and respect of the people and the impact on others $(0,81)$

Among the dominant motives and values lead a penchant for creativity (0.64) and health (0.78).

\section{Findings and Discussions}

The results of the self-evaluation of innovative qualities of the person identified groups with high, medium and low levels of innovativeness. The most numerous group of students had an intermediate level of innovativeness. It is explained by insufficient development of the innovative potential of the students.

Based on a comparative analysis of value-motivational characteristics of student's innovativeness, Kruskel-Wallis test, a correlational and a factor analysis, the value-motivational characteristics were revealed that had a statistically significant difference. It is a distinctive feature in each of the groups:

- the values of the respondents with a low level of innovativeness contained: a pleasant occupation and recreation, a commonsense motivation, although it was focused on high social status and people 
management;

- respondents with an average level of innovativeness identified such value-motivational characteristics as a survivability, a comfort, a communication, in the motivational structure an commonsense motivation and working motives and social utility motives, the total activity dominated.

- the group of respondents with a high level of innovativeness, motives of creative activity and total labour activity were expressed which indicated the predominance of activity motives value orientations.

As a result of the factor analysis, three groups of factors constituting the value-motivational characteristics of students' innovativeness were identified. The first group of factors is the structure of values in each group. The second group of factors - value-motivational sphere features with a focus on the future and the third group of factors determines the dominant motives.

For a group of students with a low level of innovativeness, such a structure of values is characteristical as follows: enjoying beauty, love, acceptance and respect of the people and the impact on others in order to achieve positive change in society. Focus on the future of this group is associated with wealth, high social ranking and people management. Among the leading motives of the group, the general activity and commonsense motivation are dominating.

The results of the factor analysis in the group with an average level of innovativeness revealed the next diverse structure of values: enjoying occupation, recreation, welfare; search and enjoying beauty, help and mercy for others; love, new knowledge in the world, nature, a human, high social status and people management, recognition and respect of the people and the impact on others, social activity in order to achieve positive change in society. In the future, the group is not focused on the development of their creative potential, the system of values and motivational aspects and structure of the dominant themes were not defined in the study. The obtained data indicate on the process of the value-motivational sphere making, its diversity and unclear structure.

In the group with a high level of innovativeness, the following value orientations were discovered: new knowledge of the world, nature, a human, high social status and people management, recognition and respect of the people and the impact on others, social activity in order to achieve positive change in society. Orientation towards the future is associated with welfare, help and compassion for others, finding and enjoying beauty, recognition and respect of people and the impact on others. The dominant motives and values are tendency for creativity and health. In the students' group with a high level of innovativeness, the value-motivational characteristics have still been on its formative stages, but it has a clear structure.

The obtained facts suggesting making a gender analysis of students' innovativeness. The boys showed better results on innovativeness index. While the creativity index in the girls' sample group was higher. Both samples groups were ready to take risks for success. Women students' sample group was a little more future-oriented than men's.

The results of the correlation analysis displayed that the young men were willing to take risks, to assist and to show mercy to others. In the future, the boys are focused on overall activity and social utility. In the girls' innovative manifestations dominated creativity, but in the future they are focused on social activity and making a positive difference in society. In general, the study examined that boys are more willing to take risks, and girls are more creative, but both samples groups into the future orientation are ready to be active in order to achieve social benefits and positive change in society.

On the basis of factor analysis, the value-motivational structure of students' innovativeness was divided into 3 groups of factors: the factors of the value-motivational structure, the factors of value-motivational characteristics of future orientation and motivational factors of value-risk characteristics for success.

The author states the following gender differences throughout 3 groups of factors:

- the value-motivational innovativeness structure of the boys has more detailed representation of the different values and motives, which are equally represented as hedonistic and social components: pleasant occupatione, recognition and respect of the people and the impact on others, comfort, social status, communication, motivation and social utility. In the group of the girls more pronounced motivational components of total activity dominated: creative activity, social utility and work motivation;

- the value-motivational characteristics of the girls' future orientation demonstrated hedonistic values (pleasant occupation, recreation, comfort), and social values and motives (communication, commonsense motivation, social status) at the same time. In the future orientation, the boys showed more pronounced social values and motives, such as: social activities to achieve positive changes in society, communication, total activity, creative activity, and social utility and work motivation;

- the value-motivational risk characteristics for success, the boys are willing to risk for the sake of wealth and high social status, as well as to provide assistance and charity, and the girls are willing to take risks and to be socially active in order to achieve positive change in society. 
It summary, it should be mentioned that tendencies of hedonistic and exploitative orientation are seen in the valuemotivational structure of students with low level of innovativeness. On the background of demonstrated value orientations on a pleasant occupation and recreation, the focus on high social status and people management were explored. Consequently, there is a tendency to achieve the status and people management without the desire for creative activity. These characteristics are the alarming symptoms. It is evident that a group of students needs a special treatment. The psychological service of the university and the faculty should do their best to develop the value-motivational students' activity. There are risks that individuals with low innovativeness would constitute a group who freeloads on more developed personalities and exploits the potential of more creative society.

The group of students with an average innovativeness level showed the most diverse palette of value orientations. It is represented both hedonistic and value-motivational aspects of social activity and creativity equally. This tendency is due to the age features of the youthful development, when some value orientations and motives are actively replaced by others. In general, value-motivational sphere is unstable and prone to serious changes under the influence of society. It is the socio-economic trends of society which will have a significant impact on the structure of the value-motivational sphere, hence, on the personality innovative developmental level as well. The obtained facts suggest the sample group of students with an average level of innovation as a group with uncertain motives structure. It confirms the need for psychopedagogical influence on the youth's motivational sphere development.

In the group with a high level of innovativeness, as well as in the group with a low level of innovation, the value orientations on a high social status and people management was revealed. Unlike the first group, the value orientations are represented by a large variety in this sample. It includes: the new knowledge of the world, nature, a human, recognition and respect of the people and the impact on others, social activity in order to achieve positive change in society. However, the motivational structure is expressed only by the creative activity. The results of the study discovered the lack of a clear motivation for the particular activity in which one can apply it. It arouses serious concerns that the motives of creative activity can be transformed into other necessities in a particular activity which is not supported by motives of social significance. It is very important the psychological service of the university and faculty know the technology of the value-motivational activity development of the person. The author comes to the conclusion that the psychological support is necessarily required to the groups with different levels of innovative qualities' manifestation as well as students with the high level of innovation.

\section{Concluding Remarks}

In the search of socio-psychological and socio-economic development priorities of modern society, the perspectives of psychological research are aimed at identifying the value-motivational personality characteristics and the formation of the youth creative activity. The certain values cultivated by society give rise to new generation of individuals who are guided by the community's values. The value-motivational youth activity is the basis of society's progress and well-being.

The diagnosis of the value-motivational innovative activity and the elaboration of the personal developmental programmes are the fundamental basis for the innovative personality potential improvement and successful selffulfillment in professional career.

\section{Refereces}

Koptyaeva O.N. (2009). Motivatsionnaya gotovnost' pedagogov k innovatsionnoy deyatel'nosti (Motivational teachers' willingness for the innovative activity): Avtoreferat dis. na soiskanie step. kand. psikhol. Nauk (Synopsis of a thesis in candidacy for a psychological degree). Yaroslavl'. $15 p$.

Krupnov A. I. (2006). Sistemno-dispozitsionnyy podkhod k izuchenie lichnosti i ee svoystv (Systemic and dispositional approach to personal study and its characteristics):Vestnik RUDN, seriya «Psikhologiya i pedagogika». (People's Friendship University of Russia Psychology and Pedagogics Bulletin), №1 (3), 63-72.

Kudinov S.I. (2007). Polisistemniy podhod issledovanya samorealizatsiy lichnosti (Polysystemic approach to self-realization research): Sibirskiy pedagogicheskiy zhurnal. (Siberian pedagogical journal) p. 337-346.

Kudinov S.I. (2013). Sootnoshenue individualno-tipologicheskih osobennostey organizovannosti i samorealizatsiy lichnosti (Correlation of individual-typological features of organization and self-realization): Vestnik RUDN, seriya «Psikhologiya i pedagogika». (People's Friendship University of Russia Psychology and Pedagogics Bulletin), №1 (2), 14-19.

Lebedeva N.M., Bushina E.V., Cherkasova L.L. (2013). Tsennosti, sotsial'nyy kapital i otnoshenie k innovatsiyam (Values, social capital and attitude to innovations) //Obshchestvennye nauki i sovremennost' (Social sciences and modernity). № 4, 28-41.

Lichnostnyy potentsial [Personal potential]. Struktura i diagnostika (2011). (Structure and diagnosis) /Pod red. D.A. Leont'eva (Under the editorship of D.A. Leontiev). 
Mikhailova O. B. Methodological Basis of Personal Innovative Capacity Research. // Vestnik Universiteta (GUU), 2010, № 21, p. 71-75. Mikhailova O.B. (2012). Vidy aktivnosti kak determinanty razvitiya innovatsionnogo potentsiala lichnosti (Types of activity as personal innovative potential determiner) I/Vestnik RUDN.- Seriya: Psikhologiya i pedagogika (People's Friendship University of Russia Psychology and Pedagogics Bulletin). №4, 35-44.

Mikhailova O.B. (2013). Psikhologiya stanovleniya innovatsionnogo potentsiala lichnosti: monografiya (Psychology of personal innovative potential development) /O.B.Mikhaylova. -Moskva: RUDN (Moscow, People's Friendship University of Russia). 215 p. 